\title{
High expression of anti-apoptotic genes in grade I and II meningiomas
}

\author{
Alta expressão de genes anti-apoptóticos em meningiomas graus I e II \\ Daniela Pretti da Cunha Tirapelli', Sarah Bomfim Menezes ${ }^{1}$, Indira Maynart Franco ${ }^{1}$, Isis Lacrose Lustosa', \\ Andressa Romualdo Rodrigues', Paulo Cézar Novais², Antônio César Mendes Santiago', Fernanda Maris \\ Peria $^{3}$, Luciano Neder Serafini4 ${ }^{4}$, Alexandre Magno da Nóbrega Marinho ${ }^{5}$, Carlos Gilberto Carlotti Jr', \\ Benedicto Oscar Colli ${ }^{1}$, Luís Fernando Tirapelli ${ }^{1}$
}

\begin{abstract}
One of the different genetic mechanisms involved in the carcinogenesis of meningiomas is influenced by interactions between proteins that induce and inhibit apoptosis. Objective: To evaluate the expression of c-FLIP, XIAP, BcL-2, caspase 3, 8 and 9, cytochrome c, APAF 1 and Smac/DIABLO genes related to apoptosis pathways. Methods: The gene expression was evaluated in 30 meningiomas (WHO grades I and II) and in 10 normal samples (from arachnoid tissue) through PCR-RT. Results: The results showed higher expression of anti-apoptotic genes in meningiomas when compared to the control group, which had a low expression of pro-apoptotic genes. Conclusion: There is a possible block in the activation of caspases through the intrinsic apoptosis pathway in meningiomas. c-FLIP modulates caspase 8 and, by inhibiting its activation due to the lack of connection with the receiver, there is a block to the FAS activation of apoptosis by its extrinsic pathway.
\end{abstract}

Keywords: meningioma; carcinogenesis; apoptosis; gene expression.

\section{RESUMO}

Um dos diferentes mecanismos genéticos envolvidos na carcinogênese de meningiomas é influenciado por interações entre proteínas que induzem e inibem a apoptose. Objetivos:Avaliar a expressão de c-FLIP,XIAP, Bcl-2, caspase 3, 8 e 9, citocromo C,APAF 1 e Smac/DIABLO, genes relacionados com as vias da apoptose. Métodos:A expressão gênica foi avaliada em trinta amostras de meningiomas (OMS grau le II) e em dez amostras normais (de aracnóide) por PCR em tempo real. Resultados: Os resultados mostraram maior expressão de genes antiapoptóticos em meningiomas quando comparados com controle, em contraste com a menor expressão de genes próapoptóticos. Conclusão: Há um possível bloqueio na ativação de caspases através da via intrínseca da apoptose em meningiomas. O c-FLIP modula a caspase 8 e, desse modo, inibindo a sua ativação pela ausência de ligação com o receptor, há um bloqueio na ativação de FAS pela via extrínseca da apoptose.

Palavras-chave: meningioma; carcinogênese; apoptose; expressão gênica.

Meningioma is the most frequent primary intracranial tumor in adults ${ }^{1}$. They arise from the meninges and are composed of neoplastic arachnoid (meningothelial) cells. They generally grow slowly and rarely show an aggressive behavior ${ }^{2,3,4,5}$.

According to the current World Health Organization histological grade system, meningiomas are classified into three grades: grade I or benign (90\%), generally following a benign clinical course; grade II or atypical (5-7\%) are associated with increased risk of recurrence; and grade III, or anaplastic (1-2\%), defined as meningiomas that have obvious malignant histology or high mitotic rates that frequently present with local and brain invasion, recurrence and even metastases $^{3,4}$. Currently, the curative treatment option is complete surgical resection ${ }^{6}$, and there is no established chemotherapy regimen for unresectable meningiomas ${ }^{7}$. Despite being benign, meningiomas have a significant rate of recurrence after surgery. While recurrence rates of benign meningiomas range from $7 \%$ to $20 \%$, recurrence of the atypical and anaplastic tumors occur at approximately $29 \%$ to $40 \%$ and $50 \%$ to $78 \%$ of the cases, respectively ${ }^{8}$. Many advances have been made in the knowledge of the different molecular mechanisms that drive tumorigenesis ${ }^{9}$.

1Universidade de São Paulo, Faculdade de Medicina de Ribeirão Preto, Departamento de Cirurgia e Anatomia, Ribeirão Preto SP, Brasil;

${ }^{2}$ Universidade de Marília, Departamento de Odontologia, Marília SP, Brasil;

${ }^{3}$ Universidade de São Paulo, Faculdade de Medicina de Ribeirão Preto, Departamento de Medicina Interna, Ribeirão Preto SP, Brasil;

4Universidade de São Paulo, Faculdade de Medicina de Ribeirão Preto, Departamento de Patologia e Medicina Legal, Ribeirão Preto SP, Brasil;

5Universidade Federal de Campina Grande, Unidade Acadêmica de Ciências Médicas, Campina Grande PB, Brasil;

Correspondence: Daniela Pretti da Cunha Tirapelli; Av Bandeirantes, 3900; 14049-900 Ribeirão Preto SP, Brasil; E-mail: lab.biomol.cirurgia@fmrp.usp.br

Conflict of interest: There is no conflict of interest to declare.

Received 14 September 2016; Received in final form 16 December 2016; Accepted 27 December 2016. 
Physiological apoptosis is a form of cell death that eliminates unwanted cells through the activation of a coordinated series of events synchronized by a unique set of gene products $^{10}$. Caspases constitute a large family of homologous proteins, whose enzymatic activity is activated in cells marked for apoptosis death. They are the central components of the apoptotic response and are generally divided into two classes: initiators, which include caspases 2, 8, 9 and 10; and the effectors, which include caspases 3, 6 and $7^{11}$. The protein inhibitors of apoptosis (IAPs) are known as endogenous inhibitors of caspases that effectively eliminate the cell death program. There are currently several human IAPs including: X chromosome linked IAP (XIAP), c-IPA1, c-IAP2, NAIP, Survivin, BRUCE and NL-IAP ${ }^{12}$. They block the apoptotic pathway mediated by mitochondria directly inhibiting initiator and effector caspases. The IAPs are regulated by cellular proteins such as the second mitochondria-derived activator of caspases/direct inhibitor of apoptosis (Smac/DIABLO), a mitochondrial protein released along with cytochrome $c$ from the mitochondria to the cytoplasm responsible for apoptotic stimulation ${ }^{13}$. During apoptosis, the inhibition of caspase, mediated by the IAP, is removed by the Smac/DIABLO proteins. When there is the stimulation of apoptosis, Smac/DIABLO proteins are released from the intermembrane space of mitochondria to the cytoplasm with cytochrome $c$. While the cytochrome $c$ directly activates the APAF1 and caspase 9, the Smac/DIABLO removes the IAP (XIAP, c-IAP1, c-IAP2, and ML-IAP), which means the inhibition of caspases initiators and effectors, empowering the apoptosis ${ }^{11,14}$. The Smac/DIABLO inhibits the interaction between the field BIR3 of XIAP with caspase 9 and field BIR 2 with caspase 3 and caspase 7 , and mitigates the inhibiting effects of XIAP on these caspases ${ }^{15}$.

Several studies have been conducted to better clarify the different genetic mechanisms involved in the carcinogenesis of meningiomas. The sensitivity of tumor cells to apoptosis is probably one of these mechanisms and is influenced, at least partly, by the interactions and the relative amount of several proteins inducing and inhibiting this process. However, the correlation of events on gene expression related to cellular apoptosis, and also the possible association with the tumor progression, are not completely clear in meningiomas ${ }^{11}$.

The purpose of this study was to examine, in meningiomas, the pattern of gene expression of the anti-apoptotic genes BCL2, XIAP, cellular FLICE-inhibitory protein (c-FLIP), and pro-apoptotic genes Smac/DIABLO, complex apoptosome, caspase 3 and caspase 8, related to extrinsic and intrinsic pathways of apoptosis using a polymerase chain reaction - real-time (PCR-RT) technique.

The characterization of these processes is paramount for a better understanding of these events and it may also lead to establishing more effective diagnostic tests and treatment ${ }^{11}$.

\section{METHODS}

For this study, 20 grade I and 10 grade II meningioma samples from adult patients were used. The selected patients had not undergone previous treatment. For the control group, we used 10 arachnoid mater samples from patients who had vascular surgery without a tumor diagnosis. The histopathologic diagnoses were based on 2016 World Health Organization criteria ${ }^{16}$. This study was approved by the Research Ethics Committee of the University Hospital of the Medical School of Ribeirão Preto of the University São Paulo.

\section{RNA extraction and cDNA synthesis}

Total cellular RNA was extracted using Trizol ${ }^{\circ}$ Reagent (Invitrogen, Carlsbad, CA, USA) and RNA was reverse transcribed to single-stranded cDNA using a High Capacity Kit (Applied Biosystems, Foster City, CA, USA) according to the manufacturer's protocol.

\section{Analysis of Gene Expression Patterns by RQ-PCR}

For the quantitative analysis of the genes under study, caspase 9 (assay ID Hs00154260_m1), cytochrome c (assay ID Hs01588973_m1), APAF-1 (assay ID Hs00559441_m1), Smac/DIABLO (assay ID 00219876_m1), XIAP (assay AI 00236913_m1), BCL2 (assay ID 00608023_ $\mathrm{m1}$ ), caspase 3 (assay ID Hs00234385_m1), caspase 8 (assay ID Hs00236278_m1) and c-FLIP (assay ID Hs0235998_m1), we used the commercially available TaqMan Gene Expression Assay-on-demand, which consists of oligonucleotides and probes (Applied Biosystems, Foster City, CA, USA). Reverse transcription was performed using $1 \mathrm{mg}$ total RNA for each sample in $20 \mathrm{~mL}$ of the total reaction mixture. The cDNA obtained was diluted 1:10 and $4.5 \mathrm{~mL}$ was used for each $10 \mathrm{~mL}$ of the RQ-PCR mixture using the TaqMan Master Mix (Applied Biosystems).

All reactions were carried out in duplicate and analyzed with the 7500 Sequence Detection System apparatus (Applied Biosystems). Data were analyzed using the ABI-7500 SDS software. The maximum standard deviation between duplicates was $10 \%$. The total RNA absorbed was normalized on the basis of the Ct value for $\beta$-Actin (ACT- $\beta$ ) gene. The variation of expression among samples was calculated by the $2-\Delta \Delta \mathrm{Ct}$ method, with the mean delta $\mathrm{Ct}$ value of the control group being used as a calibrator. To obtain the $\mathrm{Ct}$ (cycle) values, we established a threshold of 0.1 and the PCR conditions were: pre-heating at $50^{\circ}$ for $2 \mathrm{~min}$, denaturation at $95^{\circ}$ for $10 \mathrm{~min}$ and 50 cycles of amplification and quantification ( $15 \mathrm{sec}$ at $95^{\circ}$ and $1 \mathrm{~min}$. at $60^{\circ}$ ).

\section{Statistical analysis}

Comparisons of gene expression of grade I, grade II meningiomas and control samples were performed by One-way ANOVA and post-test Newman-Keuls Multiple Comparison Test. The level of significance was set at $\mathrm{p}<0.05$ in all analyses. The tests were carried out using the Graphpad Prism - version 4.0 program (Graph Pad Software Inc, San Diego, CA, USA). 


\section{RESULTS}

Expression of pro-apoptotic genes: cytochrome c, APAF1, caspase 9, Smac/DIABLO, caspase 8 and caspase 3

The mRNA levels of cytochrome C, APAF1, caspase 9, Smac/DIABLO, caspase 8 and caspase 3 in grade I and II meningiomas and control arachnoid tissue were compared. No significant difference in gene expression was
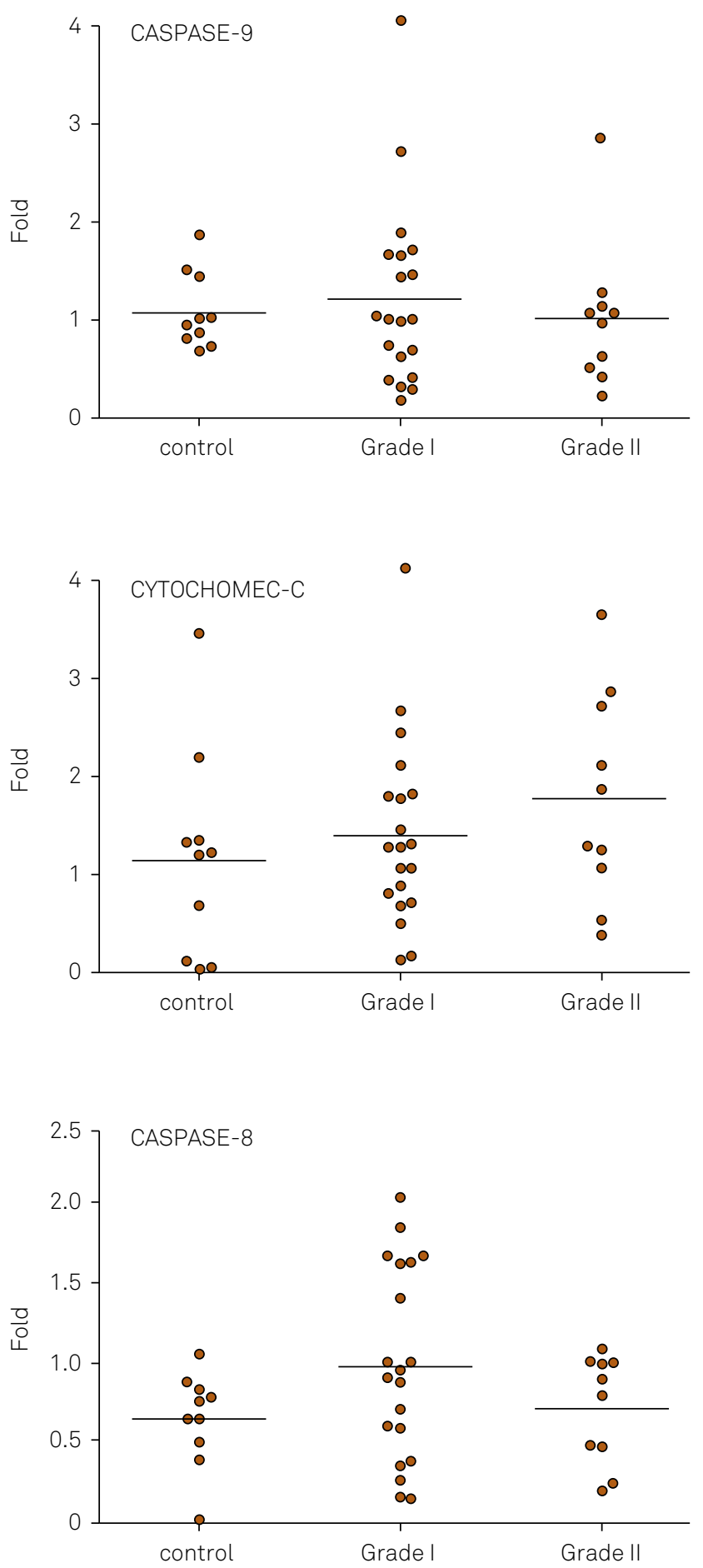

found: cytochrome $c(\mathrm{p}=0.3991)$, caspase $9(\mathrm{p}=0.7807)$, APAF1 $(p=0.6486)$, Smac/DIABLO $(p=0.5011)$, caspase 8 $(p=0.1381)$, and caspase $3(p=0.0507)$ (Figure 1$)$.

Expression of anti-apoptotic genes:XIAP, Bcl-2 and c-FLIP

The mRNA levels of the anti-apoptotic genes XIAP, Bcl-2 and c-FLIP in grade I and II meningiomas and control arachnoid tissue were compared. We observed overexpression of all
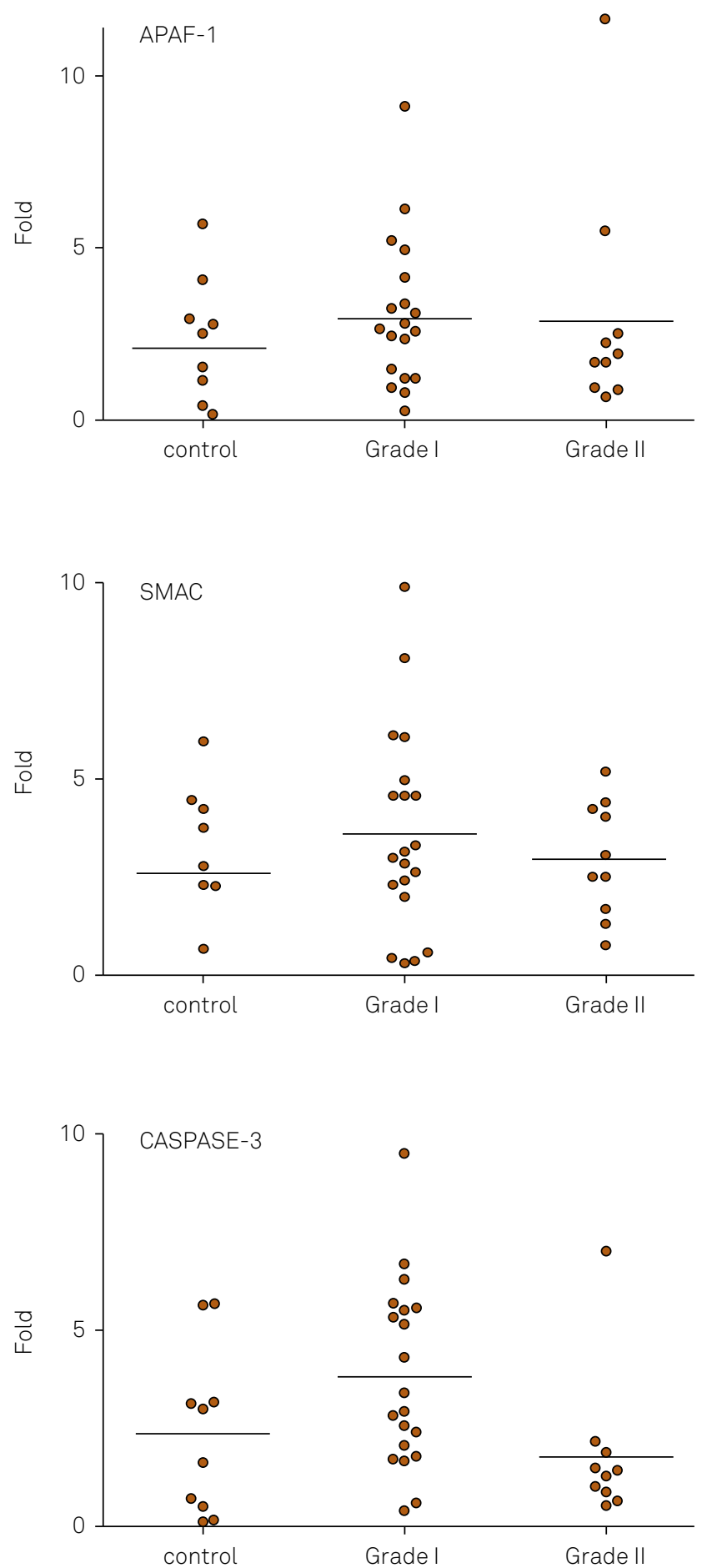

Figure 1. Representation of pro-apoptotic genes: cytochrome c ( $p=0.3991)$; caspase $9(p=0.7807)$; APAF1 ( $p=0.6486)$, Smac $(p=0.5011)$, caspase $8(p=0.1381)$, and caspase $3(p=0.0507)$ among the groups. 

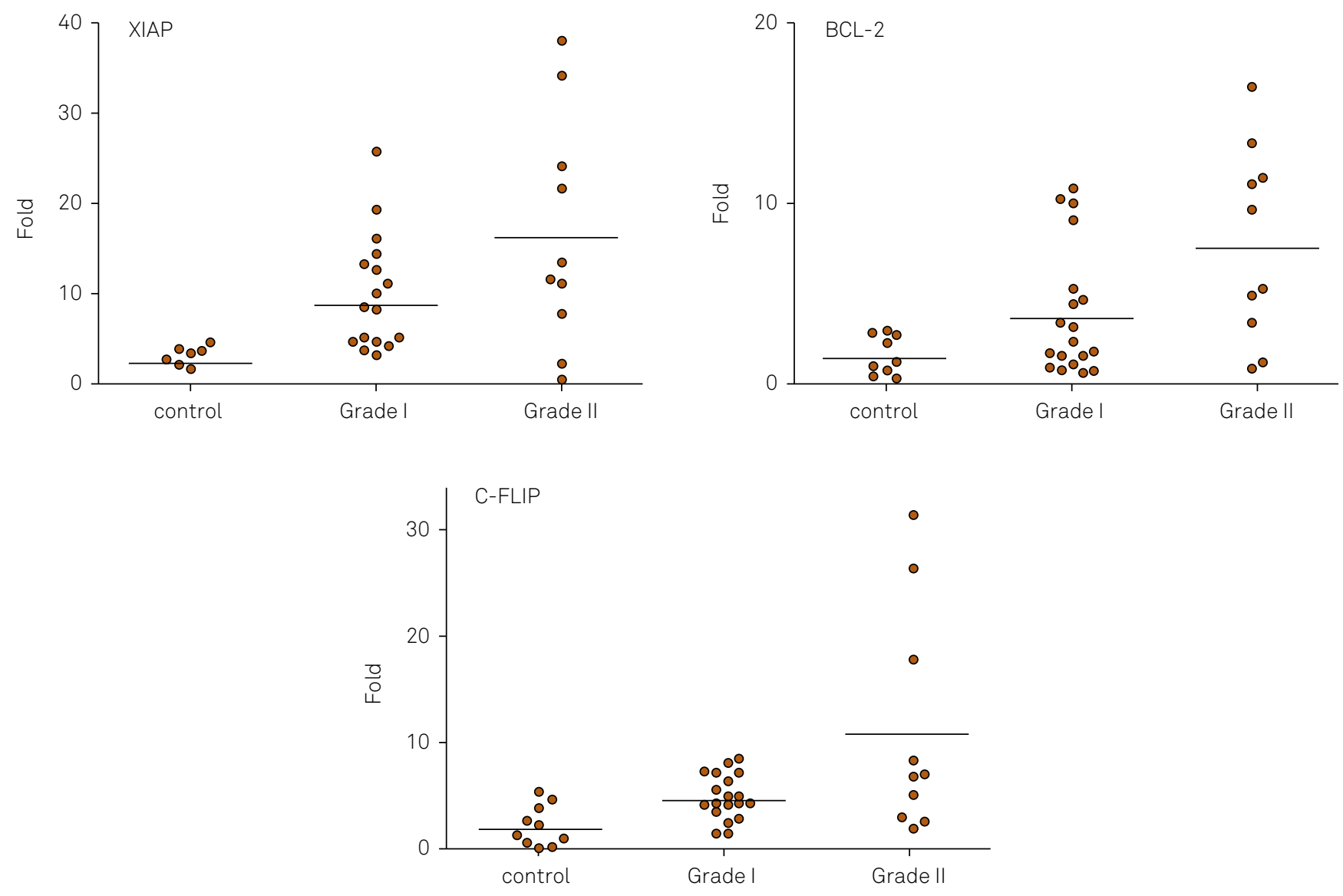

Figure 2. Representation of anti-apoptotic genes: XIAP ( $p=0.0012)$, BcL-2 ( $p=0.0020)$ and c-FLIP $(p=0.0025)$ among the groups.

genes studied in grade II meningioma tumors when compared to control arachnoid cells and grade I meningiomas: XIAP $(\mathrm{p}=0.0012)$, Bcl-2 ( $\mathrm{p}=0.0020)$ and $\mathrm{c}-\mathrm{FLIP}(\mathrm{p}=0.0025)$ (Figure 2$)$.

\section{DISCUSSION}

A series of genetic alterations lead to neoplastic transformation and development, and tumor growth is considerably influenced by the balance between cell proliferation and cell death. In meningiomas, the understanding of growth regulation is currently limited. The ratio between anti- and proapoptotic proteins appears to influence the sensitivity of cells for apoptosis ${ }^{17}$. Abnormal apoptosis is a hallmark of human tumors and the deregulation of the genes that control the apoptotic cascade is closely related to tumor development, progression and recurrence. Among the known regulators and effectors of apoptosis, the family of caspases plays an important role in the execution phases of apoptosis ${ }^{10,18}$.

Bcl2 is a member of the Bcl2 proto-oncogene family known to be important regulators of susceptibility to apoptotic cell death and proliferation, and its immunoreactivity in meningiomas has been described by several authors ${ }^{19}$. The Bcl2 protein itself is an anti-apoptotic protei ${ }^{20}$. Karamitopoulou et al. $^{21}$ observed a good correlation between histological grading of meningiomas (benign, atypical and malignant), MIB1 and TP53 protein expressions by immunohistochemistry. Their results also indicate that the presence of Bcl2 protein expression together with high MIB1 labeling index is associated with an unfavorable prognosis of the disease in benign meningiomas. Sixteen (26.6\%) of the 60 meningiomas expressed Bcl2 protein (21.6\% of the benign, $20 \%$ of the atypical and $46.1 \%$ of the anaplastic meningiomas) and the intensity of the Bcl2 protein expression was higher in malignant meningiomas than in atypical and benign samples. A higher rate of $\mathrm{Bcl} 2$ positivity was observed in recurrent meningiomas when compared to non-recurrent benign meningiomas $^{19}$. Similar results were found in this study, where the analysis of gene expression of Bcl2 by PCR-RT, demonstrated higher expression of this gene in atypical grade II meningiomas when compared to grade I.

The IAPs are known as caspase inhibiting proteins that have been reported to bind and to inhibit specific members of the caspase family. The IAPs are responsible for blocking the pathway of intrinsic apoptosis, directly inhibiting the initiator and effector caspases. They are regulated by cellular proteins like Smac/DIABLO, a mitochondrial protein released along with cytochrome $c$ of mitochondria to the cytosol, and responsible for stimulating apoptosis. Among the several IAPs, we can also highlight the XIAP and Survivin, 
important proteins that act as suppressors of apoptosis ${ }^{13}$. Our results showed a significant increase in the expression of XIAP in grade I and II meningiomas when compared to samples of arachnoid tissue used as a control. The increase in the expression of XIAP was two-fold higher when compared to the expression of Bcl2. In another study, Gogineni and colleagues also found an overexpression of XIAP protein in meningiomas when compared to control tissue; moreover, they saw that the Transforming Growth Factor $\beta$ (TGF $\beta 1$ ), involved in physiological processes such as cancer, is one of the factors responsible for the increase of XIAP expression ${ }^{22}$.

Few studies involving the expression of complex apoptosome (cytochrome $c$, caspase 9 and APAF-1) are reported in meningiomas. Our results showed a low expression of the genes that constitute the apoptosome. The same results were observed in the expression of Smac/DIABLO, with low expression in grade I and II meningiomas. This demonstrates that apoptosis mediated by intrinsic pathway is low in this type of tumor.

Rajaraman et al. ${ }^{23}$ evaluated three brain tumor types (glioma, meningioma and acoustic neuronoma) with respect to 12 single nucleotide polymorphisms from 10 genes involved in apoptosis and cell cycle control, including two caspase 8 polymorphisms (location 2q33-q34) selected for their common occurrence in the population. The haplotype analyses further implicating the chromosomal region indicated by the two caspase 8 single nucleotide polymorphisms were evaluated. The significantly increased risk of meningioma observed with the CT (haplotype) suggests that this chromosomal region either harbors or is in linkage disequilibrium with a functional polymorphism that affects meningioma risk and may be a promising candidate for brain tumor susceptibility genes ${ }^{23}$. In Koschny et al. ${ }^{7}$, caspase 8 expression showed a high variability between the tumor samples (grade I, II and III meningiomas), and there was no significant difference in caspase 8 expression between the grades of malignancy. Our results of the expression of this gene by PCR-RT showed that its expression is very low in meningiomas, and very similar in grades I, II and control samples.

The activation of caspase 3 is a central and specific event in the process of apoptosis and represents the point of convergence of multiple "executioner" apoptotic pathways and the experimental evidence on animal models the known caspases in the brain with important implications in brain development. Konstantinidou et al. ${ }^{18}$ studied the caspase 3 immunohistochemical expression in 58 primary intracranial meningiomas by using one monoclonal antibody to detect both precursor and cleaved caspase 3 (CPP32) and a second to recognize only the cleaved activated form (ASP175). Caspase 3 expression was analyzed mostly in relation to the anti-apoptotic protein BCL2, proliferation indices (KI67 and PCNA), standard clinic pathological parameters and patient disease-free survival. Caspase 3 immunostaining was observed in $62 \%$ of cases for CPP32 and in $24 \%$ for ASP175. The CPP32, but not the ASP175, labeling indices positively correlated with the mitotic index and PCNA labeling indices. Both CPP32 and ASP175 labeling indices were increased in nonbenign meningiomas. Caspase 3 predicted meningioma recurrence, regardless of how this affected disease-free survival. The weak correlation between active caspase 3 expression and the ss-DNA (recognizing exposed single-stranded-ss regions in the DNA of apoptotic cells), as well as the broader range of ASP175 values when compared to ssDNA range, indicate that caspase 3 activation may occur in the absence of cell death and apoptosis. Endogenous inhibitors of caspases exist and are known as inhibitors of apoptosis or IAPs ${ }^{24}$. The authors concluded that the present findings indicate that apoptosis in meningiomas has a prognostic value $^{18}$. These results are higher than those obtained in our studies, which evaluated the gene expression of caspase 3 through the reaction of PCR-RT, observing low expression in grade I and II meningiomas, as well as in control samples. The high expression of the clone CPP32 of caspase 3, obtained by Konstantinidou et al. ${ }^{18}$ using immunohistochemistry, can be explained by representing both the protein expression of its precursor form and the form cleaved. Despite observing a low expression of caspase 3, it was still higher when compared to the expression of caspase 8, perhaps explained by the fact that it was an effector caspase in apoptotic cascade.

The c-FLIP blocks death receptor-induced apoptosis and has been implicated in tumor progression. The c-FLIP interacts with caspase 8 , thereby preventing activation of the caspase cascade. Jönsson et al. ${ }^{25}$ investigated the endogenous expression of c-FLIP and caspase 8 in bladder carcinoma cells in relation to their sensitivity to death receptor ligation. Stable expression of c-FLIP long (c-FLIPL) was obtained by retroviral transduction and the relative ratio of c-FLIP and caspase 8 was directly correlated to resistance to anti-CD95 or tumor necrosis factor-related apoptosis-inducing ligand (TRAIL)-mediated apoptosis. Overexpression of c-FLIPL shifted the responsiveness towards resistant status and, in bladder carcinomas showing c-FLIP, is an important determinant of susceptibility to death receptor-induced apoptosis and could function as a prognostic marker for death receptor sensitivity in future immune therapy ${ }^{24}$. Also, in Koschnya et al. ${ }^{7}$, it was observed that the pattern expression of c-FLIP was evenly distributed in all tumor samples and does not depend on the grade of malignancy. We observed an increase in gene expression of meningioma c-FLIP in grades I and II when compared to normal arachnoid tissue, and it is statistically significant in grade II meningiomas. Consistent with the results of Jönsson et al. ${ }^{25}$, this increase in the expression of c-FLIP also suggests a resistance to apoptosis induced by receptors of death through its extrinsic pathway, once the action of this protein is to inhibit the activation of caspase $8^{25}$. However, no data was found in the literature related to the expression of c-FLIP in meningiomas.

The TRAIL is a cytokine of the TNF super family that induces apoptosis in tumor cells but not in most normal tissues ${ }^{26,27}$. 
Activation of agonistic TRAIL-R2 enables the Fas-associated death domain (FADD) adapter protein and the caspase 8 (FLICE, MACH) to bind to the receptor. Recruitment of caspase 8 leads to its proteolytic activation, which initiates a cascade of caspases, leading to apoptosis ${ }^{28}$. The c-FLIP is a recently-identified protein homolog to caspase 8 that lacks catalytic activity. Expression of c-FLIP has been suggested to play a significant role in controlling the susceptibility of tumor cells to the apoptosis-inducing effects of TRAIL ${ }^{29}$.

The TRAIL preferentially triggers apoptosis in tumor cells versus normal cells, thus providing a therapeutic potential. Hao et al. ${ }^{29}$ examined a large panel of glioma cell lines for their susceptibility to death ligands and demonstrated that, of four well-characterized soluble death ligands (TNF $\alpha$, FasL, Apo3L, and TRAIL), TRAIL killed the majority (54\%) of human malignant glioma cells with medium to high efficiency ${ }^{29}$. Fasmediated apoptosis of glioma cells using anti-Fas antibodies or membrane bound FasL has been reported previously. Soluble FasL apoptotic-inducing capacity is reduced when compared with membrane-bound FasL ${ }^{30}$. The use of soluble FasL in this study and the high constitutive levels of c-FLIP in the cells might explain why little Fas-mediated cell death was observed. Hao et al. ${ }^{30}$ showed that the TRAIL-resistant phenotype of some glioma cells can be converted to sensitive by treatment with protein synthesis inhibitors. This suggests the presence of short-lived apoptosis inhibitors in the cells. The demonstration of caspase 8 activation in these cells indicates that the regulation of apoptosis may occur between the death receptors and caspase 8. Apoptosis inhibitor c-FLIP is a prime candidate for this intracellular regulation because it possesses a DED through which it interrupts FADD and caspase 8 binding, preventing death-inducing signaling complex formation and apoptosis ${ }^{29}$. The c-FLIP expression in meningioma cells correlates with sensitivity to TRAIL in our study. Furthermore, protein synthesis inhibitors did not decrease c-FLIP expression at concentrations enhancing TRAIL-induced apoptosis. These results suggest that c-FLIP is unlikely to be involved directly in regulating TRAIL-induced apoptosis in meningioma cells.

In conclusion, this study showed that the gene expression of caspase 8 and caspase 3 is low in grade I and II meningiomas, suggesting that apoptosis through extrinsic pathway is small in this type of tumor. On the other hand, the gene expression of c-FLIP was investigated in meningiomas and its high expression may explain the high competition of this protein with caspase 8, thereby inhibiting their activation by the lack of connection with the receiver and blocking the Fas activation of the cascade of apoptosis by its extrinsic pathway. It was also demonstrated that the up regulation of anti-apoptotic genes Bcl-2 and XIAP blocks the activation of intrinsic caspase cascades for apoptosis in grade I and II meningiomas. Prospective studies are needed to better understand the action of these genes in the anti-apoptotic mechanisms. These studies may represent attractive novel markers for the diagnosis and follow-up of brain tumors, especially in meningiomas.

\section{References}

1. Wiemels J, Wrensch M, Claus EB. Epidemiology and etiology of meningioma. J Neurooncol. 2010;99(3):307-14. https://doi.org/10.1007/s11060-010-0386-3

2. Al-Mefty O, Kadri PA, Pravdenkova S, Sawyer JR, Stangeby C, Husain M. Malignant progression in meningioma: documentation of a series and analysis of cytogenetic findings. J Neurosurg. 2004;101(2):210-8. https://doi.org/10.3171/jns.2004.101.2.0210

3. Perry A, Gutmann DH, Reifenberger G. Molecular pathogenesis of meningiomas. J Neurooncol. 2004;70(2):183-202. https://doi.org/10.1007/s11060-004-2749-0

4. Whittle IR, Smith C, Navoo P, Collie D. Meningiomas. Lancet. 2004;363(9420):1535-43. https://doi.org/10.1016/S0140-6736(04)16153-9

5. Boldrini L, Pistolesi S, Gisfredi S, Ursino S, Ali G, Pieracci $\mathrm{N}$ et al. Expression of endothelin 1 and its angiogenic role in meningiomas. Virchows Arch. 2006;449(5):546-53. https://doi.org/10.1007/s00428-006-0273-7

6. Alexiou GA, Gogou P, Markoula S, Kyrutsus AP. Management of meningiomas. Clin Neurol Neurosurg. 2010;112(3):177-82. http://doi.org/10.1016/j.clineuro.2009.12.011

7. Koschny R, Krupp W, Xu Li-Xin, Mueller WC, Bauer M, Sinn P et al. WHO grade related expression of TRAIL-receptors and apoptosis regulators in meningioma. Pathol Res Pract. 2015;211(2):109-16. http://doi.org/10.1016/j.prp.2014.11.002

8. Takahashi JA, Ueba T, Hashimoto N, Nakashima Y, Katsuki N. The combination of mitotic and Ki-67 indices as a useful method for predicting short-term recurrence of meningiomas. Surg Neurol. 2004;61(2):149-55. https://doi.org/10.1016/S0090-3019(03)00575-5
9. Brastianos PK, Horowitz PM, Santagata S, Jones RT, McKenna A, Getz $\mathrm{G}$ et al. Genomic sequencing of meningiomas identifies oncogenic SMO and AKT1 mutations. Nat Genet. 2013;45(3):285-9. https://doi.org/10.1038/ng.2526

10. Kumar S. Mechanisms mediating caspase activation in cell death. Cell Death Differ. 1999;6(11):1060-6. https://doi.org/10.1038/sj.cdd.4400600

11. Riedl SJ, Shi Y. Molecular mechanisms of caspase regulation during apoptosis. Nat Rev Mol Cell Biol. 2004;5(11):897-907. https://doi.org/10.1038/nrm1496

12. Huang Y, Park YC, Rich RL, Segal D, Myszka DG, Wu H. Structural basis of caspase inhibition by XIAP: differential roles of the linker versus the BIR domain. Cell. 2001;104(5):781-90. http://dx.doi.org/10.1016/S0092-8674(01)00273-2

13. Siegelin MD, Kossatz LS, Winckler J, Rami A. Regulation of XIAP and Smac/DIABLO in the rat hippocampus following transient forebrain ischemia. Neurochem Int. 2005;46(1):41-51. https://doi.org/10.1016/j.neuint.2004.07.009

14. Creagh EM, Murphy BM, Duriez PJ, Duckett CS, Martin SJ. Smac/Diablo antagonizes ubiquitin ligase activity of inhibitor of apoptosis proteins. J Biol Chem. 2004;279(26):26906-14. https://doi.org/10.1074/jbc.M313859200

15. Wu G, Chai J, Suber TL, Wu JW, Du C, Wang X et al. Structural basis of IAP recognition by Smac/DIABLO. Nature. 2000;408(6815):1008-12. https://doi.org/10.1038/35050012

16. Louis DN, Perry A, Reifenberger G, Deimling A, Figarella-Branger D, Cavenee WK et al. The 2016 World Health Organization Classification of Tumors of the Central Nervous System: a summary. Acta Neuropathol. 2016;131(6):803-20. https://doi.org/10.1007/s00401-016-1545-1 
17. Takei H, Buckleair LW, Powell SZ. Immunohistochemical expression of apoptosis regulating proteins and sex hormone receptors in meningiomas. Neuropathology. 2008;28(1):62-8. https://doi.org/10.1111/j.1440-1789.2007.00852.x

18. Konstantinidou AE, Givalos N, Gakiopoulou H, Korkolopoulou P, Kotsiakis X, Boviatsis E et al. Caspase-3 immunohistochemical expression is a marker of apoptosis, increased grade and early recurrence in intracranial meningiomas. Apoptosis. 2007;12(4):695-705. https://doi.org/10.1007/s10495-006-0001-4

19. Konstantinidou AE, Pavlopoulos PM, Patsouris E, Kaklamanis L, Davaris P. Expression of apoptotic and proliferation markers in meningiomas. J Pathol. 1998;186(3):325-30. https://doi.org/10.1002/ (SICI)1096-9896(1998110)186:3<325::AID-PATH168>3.0.CO;2-U

20. Verheijen FM, Donker GH, Viera CS, Sprong M, Jacobs HM, Blaauw G et al. Progesterone receptor, bc1-2 and bax expression in meningiomas. J Neurooncol. 2002;56(1):35-41. https://doi.org/10.1023/A:1014404918118

21. Karamitopoulou E, Perentes E, Tolnay M, Probst A. Prognostic significance of MIB-1, p53, and bcl-2 immunoreactivity in meningiomas. Hum Pathol. 1998;29(2):140-5.

22. Gogineni VR, Gupta R, Nalla AK, Velpula KK, Rao JS. UPAR and cathepsin B shRNA impedes TGF- $\beta 1$-driven proliferation and invasion of meningioma cells in a XIAP-dependent pathway. Cell Death Dis. 2012;3(12):E439. https://doi.org/10.1038/cddis.2012.170

23. Rajaraman P, Wang SS, Rothman N, Brown MM, Black PM,

Fine HA et al. Polymorphisms in apoptosis and cell cycle control genes and risk of brain tumors in adults. Cancer Epidemiol Biomarkers Prev. 2007;16(8):1655-61. https://doi.org/10.1158/1055-9965.EPI-07-0314
24. Salvesen GS, Duckett CS. IAP proteins: blocking the road to death's door. Nat Re Mol Cell Biol. 2002;3(6):401-10. https://doi.org/10.1038/nrm830

25. Jönsson G, Paulie S, Grandien A. High level of cFLIP correlates with resistance to death receptor-induced apoptosis in bladder carcinoma cells. Anticancer Res. 2003;23(2B):1213-8.

26. Koschny R, Walczak H, Ganten TM. The promise of TRAIL: potential and risksvof a novel anticancer therapy. J Mol Med. 2007;85(9):923-35. https://doi.org/10.1007/s00109-007-0194-1

27. Marsters SA, Pitti RM, Donahue CJ, Ruppert S, Bauer KD, Ashkenazi A. Activation of apoptosis by Apo-2 ligand is independent of FADD but blocked by CrmA. Curr Biol. 1996;6(6):750-2. https://doi.org/10.1016/S0960-9822(09)00456-4

28. Bodmer JL, Holler N, Reynard S, Vinciguerra P, Schneider P, Juo P et al. Trail receptor-2 signals apoptosis through FADD and caspase-8. Nat Cell Biol. 2000;2(4):241-3. https://doi.org/10.1038/35008667

29. Irmler M, Thome M, Hahne M, Schneider P, Hofmann K, Steiner $V$ et al. Inhibition of death receptor signals by cellular FLIP. Nature. 1997;388(6638):190-5. https://doi.org/10.1038/40657

30. Hao C, Beguinot F, Condorelli G, Trencia A, Van Meir EG, Yong VW et al. Induction and intracellular regulation of tumor necrosis factor-related apoptosis-inducing ligand (TRAIL) mediated apotosis in human malignant glioma cells. Cancer Res. 2001;61(3):1162-70.

31. Schneider P, Holler N, Bodmer JL, Hahne M, Frei K, Fontana A et al. Conversion of membrane-bound Fas(CD95) ligand to its soluble form is associated with downregulation of its proapoptotic activity and loss of liver toxicity. J Exp Med 1998;187(8):1205-13. https://doi.org/10.1084/jem.187.8.1205 